\title{
Free Secondary Education and the Changing Roles of the Heads of Public Schools in Tanzania: Are They Ready for New Responsibilities?
}

\author{
Henry Godda \\ Department of Public Administration Leadership and Management, Tanzania Public Service College, Singida, Tanzania \\ Email: hgodda@gmail.com
}

How to cite this paper: Godda, H. (2018) Free Secondary Education and the Changing Roles of the Heads of Public Schools in Tanzania: Are They Ready for New Responsibilities? Open Journal of Social Sciences, 6, 1-23.

https://doi.org/10.4236/jss.2018.65001

Received: March 22, 2018

Accepted: May 5, 2018

Published: May 8, 2018

Copyright $\odot 2018$ by author and Scientific Research Publishing Inc. This work is licensed under the Creative Commons Attribution International License (CC BY 4.0). http://creativecommons.org/licenses/by/4.0/

\begin{abstract}
This study investigated the management capacity of heads of public secondary schools in the implementation of Free Secondary Education (FSE) policy in Singida municipality. The study was descriptive research survey which employed both qualitative and quantitative research designs. Questionnaires and interviews were used to collect data from 200 teachers, 10 school heads and 5 municipal secondary education officers. The findings indicated that heads of public secondary schools in Singida municipality possessed managerial skills to run their schools effectively despite of being faced by several challenges, like inadequate funds to cater for some of the school needs, misconception by parents that FSE policy catered for all the fees and rapid increase of student enrollment. The findings further revealed that school heads use informal and formal coping strategies like community participation and informal peer coaching to manage the challenges of FSE.
\end{abstract}

\section{Keywords}

Free Secondary Education, Management Capacity, Challenges, Heads of School

\section{Introduction}

Many countries have been investing a lot in education sector particularly in primary and secondary education. Primary and secondary education is regarded as basic education and a right that every country should guarantee to her citizens (Abagi, 1998) [1]. The realization of basic education as a link to economic and 
social development has led to several countries to provide free secondary education (UNESCO, 2000) [2].

In Tanzania, as in all countries, the government had taken many initiatives to ensure that every child has access to basic education free of charge. For instance, in 2014, the government launched the new 2014 Education and Training Policy which provides for 10 years of free and compulsory primary and lower secondary education to all citizens (MoEVT, 2014) [3]. In 2016, two years after the launch of the policy, the government abolished all fees and additional financial requirements for lower secondary education and allocated an additional Tanzania shilling 137 billion (\$62 million); sourced from cost-cutting measures and savings within the government ministries (Human Rights Watch, 2017) [4].

A number of studies indicated that the provision of free education has been accompanied by numerous challenges that impede quality education. For instance, in Kenya and Uganda, the provision of free secondary education has led to unwillingness by many parents to make any payments to schools and increased student enrolment that consequently caused other problems like heavy teaching loads, movement of students in and out of schools, teacher shortages and inadequate instructional materials (Aluko \& Adan, 2015: p. 102 [5]; Kalunda \& Otanga, 2015 [6]; Oyaro, 2008 [7]). Moreover, Morojole (2012) [8] also found that in Lesotho provision of free education has resulted into increased centralization which subsequently caused the loss of local accountability in the development of schools.

The prevalence of these challenges calls for school heads to be competent enough to manage them so as to achieve the goals of free education. Aluko and Adan (2015: p. 107) contends that successful implementation of any programme in schools depends on the managerial and leadership competences of school heads. There is also evidence (Mosha, 2004 [9]; Malekela, 2004) [10] to suggest that well prepared school managers can effectively support reforms in education and development in their schools. Kibui (2013) [11] added that personality and professional competence of heads of school highly determine efficiency of schools, which is supported by Fullan (1991) [12] who contends that heads of schools are facilitators of change at school level.

However, a study conducted in Tanzania by Onguko et al. (2008) [13] revealed that there was a shortage of training institutes for educational leaders in this country something which implied that many schools heads are promoted to headship positions without necessary skills. After being appointed, both primary and secondary school leaders are usually trained by the Agency for the Development of Educational Management (ADEM), but the training programs offered by this agency usually last for short periods of time and ADEM itself seems to lack a comprehensible plan on how to run these programs (Malekela, ibid). Besides, there is an increase in the number of both public and private schools and yet there has been far less concern with the preparation and development of school leaders in Tanzania (Mosha, ibid; Komba and Nkumbi, 2008 [14]). Based 
on this background, it is therefore imperative to examine the management capacities of school heads in the implementation of free lower secondary education in Tanzania and the challenges they face in the execution of the same programme.

This papers starts with introductory remarks, and after that, it is the literature review, followed by statement of the problem and objectives of the study. It ends with methodology, the findings and conclusion.

\section{Literature Review}

The idea of abolishing enrolment fees and other compulsory contributions in the primary and lower secondary schools in Tanzania emanated from international education commitments and other international conventions to which the country is a signatory. For instance, the most notable 1990 World Conference on Education for All (EFA) in Jomtien and the 2000 World Education Forum in Dakar required signatory countries to take basic education as a basic right for every child. With this regard all participating countries were required to have strong and sustained political commitment and enhance financial allocations to achieve this goal and meet set targets (UNESCO, 2002) [15].

On the national level the provision of free education is a response to various education and development policies such as the "Education and Training Policy 2014" and "The Tanzania Development Vision 2025". Education and Training Policy 2014 overhauled the education system, where basic education will now run from standard one to Form Four. According to the policy, basic education shall be fee free, with single textbooks for all schools and shall provide quality education recognized across the region and the world. Formulation of this policy was guided by "The Tanzania Development Vision 2025" where education is a goal in itself and recognized as a means to bring development to other sectors of economy.

Immediately, after the launching of Education and Training Policy 2014 the government issued circular number 5 which directs public bodies to ensure that education at the lower secondary schools is free for all children. In practice, this means that parents will no longer required to pay the 20,000 shillings fees that were charged to day school students and 70,000 shillings charged for students in boarding school (URT, 2016: p. 8) [16]. However, as per Education Circular No.3 of 2016, parents will still be required to make contribution for their children's education. They must purchase uniforms for school and sports activities, exercise books and pens and pay for the medical expenses of their children (URT, 2016: p. 8).

By abolishing fees and other contributions the government expects that many children from the poor families will have access to secondary education (Haki Elimu, 2017: p. 9) [17]. The enrolment is also expected to rise, as occurred in 2002, when primary education was made free and the primary net enrolment rate jumped from 59\% in 2000 to $94 \%$ in 2011 (Hakielimu, 2017: p. 10). 
The realization of education programmes in schools cannot be separated from well-established and effective school management and administrative machinery especially school headships (URT, 1995) [18]. Aluko and Adan (2015: p. 5) recognized that poor planning and limited enhancement of school heads' capacity to manage the programs negatively influenced the achievement of desired goals of Free Secondary Education (FSE) in Kenya. This incapacity limited the possible level of successes of the programme. The disharmony between the Boards of Management (BOMs) and the heads of schools also has led to haphazard and unsystematic implementation of school projects or utilization of the school funds sent by the FSE program for that matter (Kilemi \& Osita, 1999) [19].

Moreover, the study on the roles of school principals in educational improvement conducted in seven Asian countries, Bangladesh, Malaysia, Nepal, Pakistan, the Philippines, Republic of Korea, and Sri Lanka indicated that the quality of any educational programme depends on the way schools are managed; and the capacity of schools to improve teaching and learning is strongly determined by the way heads of schools manage and lead their institutions (Kandasamy \& Blaton, 2004) [20]. The secondary school manager is the principal; he or she is a major determinant of secondary education system (Liphan, 2016) [21]. The tone of the school depends on the principals' effectiveness. The quality of training acquired by them will sharpen their administrative visions and missions (Ogba \& Igu, 2014) [22].

Despite the fact that heads of schools determine the outcomes of free education they are surrounded by many challenges which make the school management to be unbearable. Free education has subjected heads of schools to various challenges related to management, financing, and politics (Hakielimu, 2017: p. 10). Due to rapid expansion of student enrolments schools experience the shortage of teachers and basic infrastructure (Ndyali, 2013 [23]; Alike, 2016 [24]). Heads of schools also face budget constrain due to inadequate fund released by governments with strict guidelines on how the money can be spent (Musalia, 2005 [25]; Njideka, 2016 [26]; Hakielimu, ibid). This happens yet there are no guidelines on how to bridge the gap or deficit in underfunded areas by the government leaving heads of schools in a dilemma (Aluko \& Adan, ibid).

Generally, the reviewed literature shows that heads of schools significantly influence the implementation of free education programs. As school leaders, heads of schools are supposed to possess knowledge and skills to manage the intricate procedures in free secondary education and challenges associated with the program. Therefore, checking on their management capacities is paramount so as to achieve the goals of providing free education in the country.

\section{Statement of the Problem}

School headship is considered as a change agent and contributing factor to the success of school programmes (Alkarni, 2014) [27]. In Tanzania after the launch of the free lower secondary education the government recognized the position of 
school heads for effective implementation of this programme. According to Government Education Circular Number 3 of 2016 heads of school are expected to supervise all academic, administrative and management issues in schools.

However, the effectiveness of heads of school in Tanzania has been questioned by various studies. For instance, Mtavangu (2010) [28] associated irregular attendance of students and teacher absenteeism to poor supervision by heads of schools. It was also reported that poor supervision of teaching and learning activities by school heads has caused poor learning outcomes-students are not learning what they should be (Massawe, 2014) [29]. Some of Heads of schools have little knowledge and skills to manage conflicts (Ignace, 2014) [30] and they are not able to articulate and involve teachers and students in realizing the school goals and mission (Massawe, ibid). Moreover, Mkanga (2016) [31] reported that Heads of secondary schools were not familiar with the concept instructional leadership and they did not undertake classroom observations. Despite of all these weaknesses reported in the school leadership in Tanzania there are no clear strategies stipulated in the new Education and Training policy of 2014 to improve management and leadership of schools.

In Singida Municipality the managerial capacities of Heads of public secondary schools are questionable. Though, fifteen (15) out of seventeen (17) heads of public secondary schools had attended a leadership and management course at the Agency for the Development of Educational Management they lacked continuous training on professional development (TAHOSSA, 2015) [32]. According to Tanzania heads of secondary schools association (TAHOSSA) few professional training programmes were conducted for Heads of Schools (HoS) and lasted for two (02) to three (03) days. It is, therefore, in this context that the researcher investigated the management capacities of HoS in the implementation of free lower secondary education in Tanzania taking Singida municipality as a case of study.

\section{Objectives of the Study}

The study was guided by the following research objectives:

1) To investigate managerial capacity of heads of public secondary schools in Singida municipality.

2) To explore challenges faced by heads of schools in the implementation of free lower secondary education programme in Singida Municipality

3) To identify strategies that heads of schools employ to cope with challenges associated with the provision of free lower secondary education in Singida $\mathrm{Mu}-$ nicipality.

\section{Research Questions}

1) What is the status of managerial capacity of HoS in Singida Municipality?

2) What are the challenges faced by HoS in the implementation of free lower secondary education programme in Singida Municipality? 
3) What are the strategies used by HoS to cope with the challenges associated with provision of free lower secondary education in Singida Municipality?

\section{Contribution of the Study}

The findings of this study are expected to provide useful information about the real situation of public secondary school management following the implementation of free education policy. By knowing the management capacity of school heads, the improvements on their managerial skills may be made possible. The findings of this study also will shed new light and contribute to the already existing literature concerning free education policy in Tanzania.

\section{Methodology}

The study was descriptive research survey which employed both qualitative and quantitative research designs. Quantitative data were analyzed using the statistical package for Social Science (SPSS) version 21 computer programme to generate the statistics relevant to this study. Qualitative data were subjected to content analysis whereby the responsive to the data being presented is mostly concerned with seeing what data themselves suggest (Cohen, 2000) [33].

The study was conducted in Singida municipality. The municipal has seventeen (17) public secondary schools. Ten (10) schools were involved in this study. The required sample of schools was obtained by systematic random sampling. The list of secondary schools was taken from the office of Municipal Secondary Education Officer' and then arranged alphabetically in ascending order. The first school was selected with a random start " $r$ " in the list from 1 to " $k$ " sample, where $k=N / n$ sample intervals; $N$ is total number of schools in the list and $n$ is a required sample size. After the selection of first sample, every $k$ th unit was included where $r$ was greater than or equal to 1 and smaller than or equal to $k$.

Two hundred and fifteen (215) respondents participated in the study. Samples from the population were obtained from a table for determining sample size which was published in 1960 by National Education Association. There are 459 secondary school teachers, 17 heads of secondary schools and 5 municipal secondary education officers in Singida municipality. Thus a sample of 215 is enough to represent the targeted population. The composition of this sample included five (5) Municipal Secondary Education Officers (MSEOs), ten (10) heads of schools (HoS), and two hundred (200) classroom teachers. Purposive sampling was used to select MSEOs with certain titles and qualifications. Classroom teachers were selected through stratified random sampling and simple random sampling. First, teachers were located into two strata through stratified sampling. The first stratum constituted of teachers who taught at more than one school and the second stratum contained teachers who worked at one school. Thereafter, simple random sampling was used to get number of teachers from each stratum that formed a sample. Each Head of selected school constituted the sample and they were selected through purposive sampling due to the virtue of 
their offices.

Data for this study was collected through various methods since no single method could act in isolation. The mixed method in data collection aimed at avoiding bias and distortion of the reality (Cohen, ibid). In this case, the researcher collected data through interviews and questionnaires. The researcher adapted and modified a "Principals Management Skills Survey questionnaire (see Appendix I) which was developed by Njideka (ibid). The questionnaire was used to solicit information from teachers and MSEOs about the management capacity of HoS. Interviews were also used to collect information from MSEOs. Different questionnaire was developed to collect information from HoS about the challenges of FSE which face Hos and the strategies used by HoS to cope with those challenges (see Appendix II).

However, the study did not seek the opinions from HoS concerning their management capacities because people's self views have a tenuous relationship with their actual behaviors and performance (Dunning et al., 2004) [34]. Dunning and his colleagues added that people usually overrate themselves and therefore other people's views of a person's performance prove more accurate than that person's self-assessment. The questionnaire items which assessed the management capacity of school heads were arranged in three clusters namely instructional leadership skills, personnel management skills, and financial management skills as shown in Appendix I. Each of the items was on a 5 point liket-scale of Done (D), Well done (WD), Partially done (PD), Not done (ND) and Not sure (NS) as it appears in Appendix I.

To ensure the validity and reliability of research instrument pilot study was conducted at one school in the targeted population but it was not included in the final study. The aim here was to test understanding and difficulty of questions. The pilot study also aimed to check if the format was easy to follow; if the flow of information was logical; and if the respondents would interpret the items in the instruments in the same way each time they read them.

\section{The Study Findings and Discussions}

\subsection{Managerial Competences of Heads of Public Secondary Schools}

This session examined the managerial competences of school heads in the following areas of school management: instructional leadership, personnel management and financial management. The findings are indicated in the tables below:

\subsubsection{Instructional Leadership Capacity of School Heads}

Research question 1 sought to find out managerial capacity of school heads including their instructional leadership skills. Instructional leadership basically refers to actions school leaders take to improve teaching and learning (King, 2002) [35]. As instructional leaders, the roles of school heads cover three dimensions; defining the school's mission, managing the instructional programs, and creat- 
ing a positive school climate. With this regard, school heads are expected to posses instructional leadership skills to carry out these roles and the findings from this study as summarized in Table 1 which indicates that heads of public secondary schools in Singida municipality had such skills.

The findings in Table 1 indicate that the heads of schools had abilities to perform their instructional leadership responsibilities as modes of the majority of items are whether "1" or "2" which stand for "Done" (D) and "Well Done". This implies that the heads of schools were capable in doing their responsibilities related to the instructional leadership and management. The findings are in agreement with Kamete (2014) [36] who found that that majority of heads of public secondary schools in Mbeya region have leadership skills to encourage academic staff to improve on the quality of classroom teaching and learning. Though, the findings are contrary to Esudu (2010) [37] who reported that there is absent of instruction supervision in Tanzania's secondary schools.

There is a link between the performance of teachers and instructional supervision (Gerumi, 2002) [38]. Zepeda (2013) [39] affirmed that instructional supervisors must be available to upgrade lifelong learning skills and promote professional raise up and growth among teachers. Heaton and Lewis (2009) [40] added that instructional leadership is a significant factor in facilitating, improving, and promoting teachers' classroom instructional practices and the academic progress

Table 1. Mode and standard deviation on instructional leadership competences of school heads as reported by teachers and municipal secondary educational officers (MSEOs) respectively.

\begin{tabular}{|c|c|c|c|c|c|c|c|}
\hline \multirow[t]{2}{*}{ S/N } & \multirow[t]{2}{*}{ Items } & \multicolumn{3}{|c|}{ Teachers $(\mathrm{N}=200)$} & \multicolumn{3}{|c|}{$\begin{array}{l}\text { Municipal secondary education } \\
\text { officers }(\mathrm{N}=5)\end{array}$} \\
\hline & & Mode & SD & Remarks & Mode & SD & Remarks \\
\hline 1. & Heads of school observe teaching and learning activities in classrooms & 3 & 0.883 & $\mathrm{PD}$ & 3 & 0.000 & $\mathrm{PD}$ \\
\hline 2. & Heads of school supervise teachers' lesson plans and schemes of work & 2 & 0.555 & WD & 2 & 0.000 & WD \\
\hline 3. & $\begin{array}{l}\text { Heads of school make available facilities accessible to all teachers and } \\
\text { students }\end{array}$ & 2 & 0.631 & WD & 2 & 0.000 & WD \\
\hline 4. & $\begin{array}{l}\text { Heads of school evaluate the planning and implementation of } \\
\text { curriculum programmes }\end{array}$ & 3 & 0.936 & $\mathrm{PD}$ & 1 & 0.894 & $\mathrm{D}$ \\
\hline 5. & $\begin{array}{l}\text { Heads of school give teachers suggestions as to how they can improve } \\
\text { their teaching }\end{array}$ & 1 & 0.742 & $\mathrm{D}$ & 1 & 0.447 & $\mathrm{D}$ \\
\hline 6. & Heads of school jointly solve classroom problems with teachers & 1 & 0.809 & $\mathrm{D}$ & 2 & 0.000 & WD \\
\hline 7. & Heads of school monitor students' works & 3 & 0.948 & $\mathrm{D}$ & 1 & 0.798 & $\mathrm{D}$ \\
\hline 8. & $\begin{array}{l}\text { Heads of school ensure proper records school like attendance registers } \\
\text { and student enrolment }\end{array}$ & 2 & 0.504 & WD & 2 & 0.000 & WD \\
\hline 9. & $\begin{array}{l}\text { Heads of school ensure that staff in different departments and work } \\
\text { positions work cooperatively and not antagonistically for the common } \\
\text { goals of schools }\end{array}$ & 1 & 0.697 & $\mathrm{D}$ & 1 & 0.440 & $\mathrm{D}$ \\
\hline 10. & $\begin{array}{l}\text { Heads of school make sure that subjects and classes are assigned to } \\
\text { teachers according to their qualifications and competences }\end{array}$ & 2 & 0.708 & WD & 2 & 0.447 & WD \\
\hline
\end{tabular}

Source: Field data (2018). 
of students. Instructional leadership (IL) also develops efficient instructional systems (Monnypenny \& Prideaux, 2013) [41] and satisfies work environment for teachers as well as desirable learning conditions for students (Hallinger \& Walker, 2014) [42].

However, the findings shows that head of schools partially observe teaching in classrooms and seldom evaluate the planning and implementation of curriculum programmes as indicated by the responses of both teachers and MSEOs. This phenomenon suggests that the situation reported by World Bank (2010) [43] that Tanzanian teachers spend less time teaching in classrooms and requiring students to copy and memorize notes on the board might have not been significantly improved. Lwaitama and Galabawa (2008) [44] associated these inefficiencies at school level to the lack of effective teacher management and supervision. The Ministry of education through the secondary education development programme II document demanded heads of schools to supervise the teaching programme and ensure high quality teaching and learning as well as effective use of time for entire school day. Fullan (1992) [45] contended that school improves when heads of schools and teachers observe each other teaching and provide each other with useful evaluation of teaching. This assertion is supported by the finding of study conducted by Mobegi et al. (2010) [46] in Gucha district, Kenya that principals/heads of schools should engage in classroom observations to ensure that a variety of teaching methods are used.

\subsubsection{Personnel Management Capacity of School Heads}

This section aimed to examine the capacity of school heads in personnel activities. Personnel management is a task area in management dealing with human resources to be supplied and managed. As the personnel managers of schools, school heads are charged with such human resource management responsibilities such as: ensuring professional development of teachers, motivating their staff; promoting and disciplining them as well as appraising their performance (Femi \& Segun, n.d) [47]. This study sought to investigate personnel management capacity of school heads because personnel management encourages making the best use of the skills and capabilities of school staff for attaining school goals and objectives in FSE. The findings obtained were summarized in Table 2.

The findings in Table 2, show that the heads of schools were very capable in managing human resources at their schools as modes for the majority of items is " 2 " which stands for "Well done". These findings suggested that the heads of school demonstrated abilities in managing human resources-teachers and support staff in their schools. The findings disagree with the report by Ignace (ibid) that heads of secondary schools in Tanzania had little knowledge and skills on how to manage conflicts among teachers and between teachers and students. The findings also deviate from the results reported by Mfaume and Bilinga (2017) [48] that among other factors the teachers' professional malpractices in Tanzanian public secondary schools such as violent behaviors and sexual 
Table 2. Mode and standard deviation on personnel management capacity of school heads as reported by teachers and municipal secondary educational officers (MSEOs) respectively.

\begin{tabular}{|c|c|c|c|c|c|c|c|}
\hline \multirow[t]{2}{*}{$\mathrm{S} / \mathrm{N}$} & \multirow[t]{2}{*}{ Items } & \multicolumn{3}{|c|}{ Teachers $(\mathrm{N}=200)$} & \multicolumn{3}{|c|}{$\begin{array}{c}\text { Municipal secondary } \\
\text { education officers }(\mathrm{N}=5)\end{array}$} \\
\hline & & Mode & SD & Remarks & Mode & SD & Remarks \\
\hline 1. & Heads of school keep records of staff properly and accurately & 2 & 0.754 & WD & 2 & 0.000 & WD \\
\hline 2. & Heads of school model the behaviors they expect from staff & 2 & 0.812 & WD & 5 & 0.785 & NS \\
\hline 3. & Heads of school communicate effectively and timely with staff & 2 & 0.702 & WD & 2 & 0.425 & WD \\
\hline 4. & Heads of school motivate, encourage and persuade their staff & 2 & 0.929 & WD & 2 & 0.447 & WD \\
\hline 5. & Heads of school praise in public and criticize in private & 3 & 1.010 & $\mathrm{PD}$ & 5 & 0.518 & NS \\
\hline 6. & $\begin{array}{l}\text { Heads of school involve staff in decision-making and matters } \\
\text { concerning staff }\end{array}$ & 2 & 0.865 & WD & 2 & 0.000 & WD \\
\hline 7. & Heads of school delegate duties and authorities to capable staff & 2 & 0.760 & WD & 2 & 0.000 & WD \\
\hline 8. & Heads of school do not take sides in conflict resolutions & 1 & 0.907 & $\mathrm{D}$ & 2 & 0.624 & WD \\
\hline 9. & Heads of school defuse tense situations and negotiate solutions & 2 & 1.129 & WD & 2 & 0.000 & WD \\
\hline 10. & $\begin{array}{l}\text { Heads of school encourage and enable appropriate professional } \\
\text { development of staff }\end{array}$ & 3 & 1.080 & $\mathrm{PD}$ & 1 & 0.758 & WD \\
\hline
\end{tabular}

Source: Field data (2018).

abuse are due to lack of good management of teachers.

Proper management of human resources in schools is paramount because it determines how structural allocation of these resources will produce the expected results. With this regard heads of schools are expected to be competent enough to help teachers and other staff to improve their weakness, motivating them; setting expectations and being role models in performance (Mbiti, 2007 [49]; Ikediugwu, 2016 [50]; Adaegbe, 2016 [51]). While heads of schools effectively manages human resources particularly teachers student performance improves (Gerumi, ibid) and vice-versa of this resulted into irregular attendance of teachers and poor teaching in classrooms (Mtavangu, ibid).

\subsubsection{Financial Management Capacity of School Heads}

In this section the study explore the performance of school heads in managing school funds and other assets with monetary values. The financial management responsibilities of school heads include among others preparation and use of budget for decision making, keeping inventory of school assets, and raising funds (Njeru, 2004) [52]. As financial management determines whether or not schools will achieve its objectives (Orlosky, 2004) [53] it was then necessary to investigate the capacity of school heads in the manage school financial resources. The findings are summarized in Table 3.

The findings in Table 3, generally confirm adequate performance of school heads in the aspects of financial management as mode for the majority of items is "2" which stands for "Well done". These findings concur with the findings of Mgeni (2015) [54] who found that heads of secondary schools in Sengerema 
Table 3. Mode and standard deviation on financial management capacity of school heads as reported by teachers and municipal secondary educational officers (MSEOs) respectively.

\begin{tabular}{|c|c|c|c|c|c|c|c|}
\hline \multirow[t]{2}{*}{ S/N } & \multirow[t]{2}{*}{ Items } & \multicolumn{3}{|c|}{ Teachers $(\mathrm{N}=200)$} & \multicolumn{3}{|c|}{$\begin{array}{l}\text { Municipal secondary } \\
\text { education officers }(\mathrm{N}=5)\end{array}$} \\
\hline & & Mode & SD & Remarks & Mode & SD & Remarks \\
\hline 1. & $\begin{array}{l}\text { Heads of school supervise and monitor expenditure of school funds } \\
\text { per government directives and financial regulations }\end{array}$ & 2 & 0.647 & WD & 2 & 0.000 & WD \\
\hline 2. & $\begin{array}{l}\text { Heads of school jointly prepare school budget with the management } \\
\text { staff and heads of department }\end{array}$ & 2 & 0.847 & WD & 2 & 0.000 & WD \\
\hline 3. & Heads of school prioritize financial allocation according to needs & 4 & 0.498 & ND & 1 & 2.191 & $\mathrm{D}$ \\
\hline 4. & $\begin{array}{l}\text { Heads of school ensure that school budgets reflect agreed goals and } \\
\text { objectives }\end{array}$ & 2 & 0.855 & $\mathrm{PD}$ & 1 & 0.000 & $\mathrm{D}$ \\
\hline 5. & $\begin{array}{l}\text { Heads of school delegate the mechanism of financial matters to } \\
\text { capable staff }\end{array}$ & 2 & 0.849 & $\mathrm{D}$ & 2 & 0.000 & WD \\
\hline 6. & Heads of school work within the constraints of school budgets & 2 & 0.654 & WD & 2 & 0.000 & WD \\
\hline 7. & Heads of school keep school financial records accurately & 2 & 0.696 & WD & 2 & 0.000 & WD \\
\hline 8. & $\begin{array}{l}\text { Heads of school give true information about financial positions of } \\
\text { their schools }\end{array}$ & 2 & 0.844 & $\mathrm{D}$ & 2 & 0.000 & WD \\
\hline 9 & Heads of schools use school budget for decision making & 3 & 0.492 & $\mathrm{PD}$ & 1 & 0.000 & $\mathrm{D}$ \\
\hline 10 & Heads of schools keep inventories of school assets properly & 2 & 0.473 & WD & 2 & 0.000 & WD \\
\hline
\end{tabular}

Source: Field Data (2018). 
Table 4. Responses on implementation challenges of FSE.

\begin{tabular}{cccc}
\hline Challenges & $\begin{array}{c}\text { Teachers } \\
(\mathbf{N}=200)\end{array}$ & $\begin{array}{c}\text { Heads of } \\
\text { schools } \\
(\mathbf{N}=10)\end{array}$ & $\begin{array}{c}\text { Municipal secondary } \\
\text { education officers } \\
(\mathbf{N}=5)\end{array}$ \\
\hline High enrolment & $108(54 \%)$ & $8(80 \%)$ & $5(100 \%)$ \\
Misconception of parents about FSE & $93(46.5 \%)$ & $6(60 \%)$ & $5(100 \%)$ \\
Delayed fund & $25(12.5)$ & $1(10 \%)$ & - \\
Inadequate fund & $171(85.5 \%)$ & $10(100 \%)$ & - \\
$\begin{array}{c}\text { Reduced community participation } \\
\text { in school projects }\end{array}$ & $27(13.5 \%)$ & $2(20 \%)$ & - \\
\hline
\end{tabular}

Source: Field data, 2018.

(46.5\%) teachers, 6 (60\%) heads of schools and all 5 (100\%) MSEOs; inadequate and restricted funds as indicated by $171(85.5 \%)$ teachers, $10(100 \%)$ heads of schools and 2 (40\%) MSEOs.

The findings above are consistent with the findings of Hakielimu (2017: p. 11) that capitation grants disbursed to secondary school were attached with strict guidelines as stipulated in Education Ministry circular no. 6 of 2015 as "Mwongozo wa Matumizi ya Ruzuku" of 28 December 2015. The restrictions in the expenditure of school funds is vital to ensure that there is no misuse of funds though Coleman (2003) [57] contends that the feature of financial delegation which schools might highly value is its flexibility it provides. There should be flexibility in the spending of funds so as schools can meet its perceived needs and make quick responses where necessary. The findings also support the report by Hakielimu (2017: p. 14) that some parents had misconception that "fee free basic education policy" did not require them to contribute anything towards education of their children. Though in reality Education Circular No. 6 of 2015 (URT, 2015) [58] stated costs such stationery and medical expenses should be incurred by parents.

The findings of this study are also similar to the results obtained in Kenya by Mutisya (2011) [59] which indicated that free secondary education had led to high enrollment of students in secondary schools. The increase in enrollment is an indication of a positive effect of FSE as more children from disadvantaged families and groups get equitable access to secondary education following abolition of school fees and some administrative costs which were paid by parents (Kattan, 2006) [60]. Though, poor planning to accommodate the increased number of students had resulted into detrimental effects on the quality of education in Tanzania such as overcrowded classes and shortage of teachers (Twaweza, 2016) [61].

Moreover, the findings endorsed the report by Ngowi (2015) [62] who recognized that the capitation grants sent to secondary schools in Kinondoni municipality was insufficient. According to government Education Circular No. 3 of 2016 (URT, 2016: p. 2) school boards after receiving approval of councils and 
regional authorities can solicit voluntary contributions from parents to cover some expenses such as provision of mid-day meals for day students; ensuring security of school property and hiring temporary teachers for science, mathematics and technical subjects. This practice suggests that the money disbursed by government might be inadequate to meet perceived needs of schools. Besides, the Citizen newspaper of $18^{\text {th }}$ January 2016 reported that some schools lacked money to pay security guards and temporary teachers for science and mathematics. This phenomenon further affirms that schools receive inadequate fund to cater some of the expenses.

\subsection{Strategies for Coping with the Implementation Challenges of FSE}

The respondents were asked to indicate strategies employed by heads of schools (HOS) to cope with implementation challenges of FSE. The responses are summarized in Table 5.

The findings in Table 5 indicate that community and parent participation was one of the strategies used by HOS to cope with the challenges of FSE as reported by 188 (94\%) teachers, all 10 (100\%) responding HOS and all 5 (100\%) MSEOs. This finding resembles the finding by Njunwa (2010) [63] who found that in Morogoro municipality community and parents participated in school development projects like building classrooms and teachers' houses by giving monetary or material contributions. Akobour et al. (2015) [64] also found that in Ghana local community participation in school development projects had increased the number of education infrastructures and managed to reduce the problem of overcrowded classrooms.

Merging of classes was also a strategy for heads of schools to cope with the implementation challenges of FSE as stated by 153 (76.5\%) teachers and $8(80 \%)$ heads of schools. The combination of classes was done perhaps to overcome the shortage of classrooms due to highly increase of student enrollment. Though, merging of classes can solve the problem of inadequate classrooms it creates congested ones. Large classes cause hindrance in the teaching-learning process

Table 5. Heads of schools' strategies to cope with the challenges of FSE.

\begin{tabular}{cccc}
\hline Challenges & $\begin{array}{c}\text { Teachers } \\
(\mathbf{N}=\mathbf{2 0 0})\end{array}$ & $\begin{array}{c}\text { Heads of } \\
\text { schools } \\
(\mathbf{N}=10)\end{array}$ & $\begin{array}{c}\text { Municipal secondary } \\
\text { education officers } \\
(\mathbf{N}=5)\end{array}$ \\
\hline Community and Parent participation & $188(94 \%)$ & $10(100 \%)$ & $5(100 \%)$ \\
Merging Classes & $153(76.5 \%)$ & $8(80 \%)$ & - \\
Establishing remedial classes & $35(17.5)$ & $1(10 \%)$ & - \\
$\begin{array}{c}\text { Peer coaching and Mentorship } \\
\text { Creating awareness to parents about } \\
\text { their roles in FSE }\end{array}$ & $22(11 \%)$ & $8(80 \%)$ & $5(100 \%)$ \\
\hline
\end{tabular}

Source: Field data, 2018. 
(Epri, 2016) [65]. For instance, large classes negatively affect teachers' professional satisfaction and enthusiasm of teaching (Blatchford et al., 2003) [66] as well as classroom activities and instructional techniques (Yaman \& Uygulamanda, 2009) [67]. In case of remedial classes, these classes give students who did not understand the lessons in the normal class time due to overcrowded classrooms opportunities to get more assistance from teachers. However, remedial classes subjected teachers to big teaching workload.

Heads of schools also managed the challenges of FSE by sharing experiences and knowledge among themselves and the newly appointed school heads were being coached and mentored by HoS who were more experienced. This response was given by $22(11 \%)$ of responding teachers and $8(80 \%)$ of responding heads of schools. The finding agrees to the observations made in Shinyanga by Kuluchumila (2014) [68] where heads of schools used informal coaching through mobile phones to assist each other and developing their leadership skills. Kuluchumila also recognized that experienced heads of schools were used as mentors to the newly appointed school heads. Lindon (2011) [69] contends that coaching can assist in the process of up skilling the school workforce in times of change. He further argues that coaching unlock people's potentials to maximize their own performance.

Besides, the study revealed that heads of school created awareness to parents on their roles to the education of their children in FSE as indicated by 107 (53.5\%) teachers and 7 (70\%) heads of schools. This practice of HOS could have aimed to clear the misconception of parents that in the FSE they were not supposed to incur any cost for their children's education as stated prior in this report. Heads of schools usually used meetings to sensitize parents about FSE and through their local leaders especially in Ward Development Committees (WDCs) where heads of schools are members. According to Hakielimu (ibid) parents had misconception about "fee free education" policy because they lacked information about this policy" from the governments; and they were confused by contradicting statements from some political leaders. Therefore, it is important that HoS take initiatives to educate parents about FSE. Archer et al. (2010) [70] asserted that participation of parents in the implementation of educational policies can be progressive if policy makers take greater efforts to popularize the policies and make them accessible to parents in simple formats and even in local languages.

\section{Limitations of the Study}

Due to financial constraint and limitation of time, the study assessed few aspects of managerial competency and excluded other managerial skills required by school headships. The study also involved only school heads, district education officers, and teachers. Other key stakeholders of schools such as parents, school board members and school inspectors were not involved in the study.

\section{Conclusion}

Generally, the findings indicated that the provision of free education has 
brought various implementation challenges which added some roles to the heads of public secondary schools. The challenges were such as high student enrollment and inadequate funds to meet the perceived needs of schools. Despite of these challenges, the heads of public secondary schools in Singida municipality were ready to take the new responsibilities associated with the implementation of free education policy. The findings revealed that the heads of schools had managerial skills for effective school administration specifically in the areas of instructional leadership, personnel and financial management.

\section{Recommendations of the Study}

From the study findings and conclusion, two kinds of recommendation are made for practice and for further studies.

\subsection{Recommendations for Practice}

1) Local governments should create other sources of income to rid away from depending solely on the central government. This includes mobilizing community resources (human and non-human) to improve the school infrastructures.

2) More financial decision-making power especially on the expenditures of central government grants should be devolved to the school level where the specific needs of students and teachers can be easily identified and met.

3) Locally organized in-service training programs should be in place to continue improving the leadership skills of school heads.

\subsection{Recommendations for Further Study due to Some Limitations of This Study}

1) Similar studies should be conducted in other districts in Singida region and other regions to investigate the same issue for better generalization. This study has covered only ten public secondary schools in Singida Municipality.

2) Other key stakeholders of schools such as parents, school board members and school inspectors should be involved in future similar studies.

3) The study can be repeated in some years to come since it was conducted after few years of implementing free education policy in the secondary education. This might identify more promising outcomes of free lower secondary education programme rather than the identified challenges.

\section{References}

[1] Abagi, O. (1998) National Legal Frameworks in Domesticating Education as a $\mathrm{Hu}$ man Right in Kenya. IPAR, Nairobi.

[2] UNESCO (2000) Primary and Secondary Education Management Issues in Tanzania. http://unesdoc.unesco.org/images/0014/001490/149057e.pdf

[3] MoEVT (2014) 2014 Educational and Training Policy: Government Printers.

[4] Human Rights Watch (2017) "I Had a Dream to Finish School" Barriers to Secondary Education in Tanzania.

https://www.hrw.org/sites/default/files/accessible_document/tanzania0217_-accessi 
ble.pdf

[5] Aluko, J.O. and Adan, A. (2015) Constraints of Implementing Free Secondary Education in Mandera West Sub-County, Mandera County, Kenya. Journal of Education and Practice, 6, 102-111. http://files.eric.ed.gov/fulltext/EJ1082462.pdf

[6] Kalunda, L.M. and Otanga, H. (2015) Challenges in Provision of Free Primary Education in Public Primary Schools in Mombasa County, Kenya. International Journal of Humanities, Social Sciences and Education, 2, 62-72.

[7] Oyaro, K. (2008) Free Secondary Schooling Policy Faces Testing Times: Inter-Press News Agency.

[8] Morojele, P. (2012) Implementing Free Primary Education in Lesotho: Issues and Challenges. Journal of Social Sciences, 32, 37-45. https://doi.org/10.1080/09718923.2012.11893050

[9] Mosha, H.J. (2004) New Direction in Teacher Education for Quality Improvement in Africa. Papers in Education and Development, 24, 25-68.

[10] Malekela, G.A. (2004) Report of Assessment on the Impact of Participation of Head Teachers in the Three Month Certificate Course in Management Skills. Report Submitted to the Agency for the Development of Educational Management (ADEM), Bagamoyo.

[11] Kibui, A.W. (2013) Transformational Leadership in Schools Management and Capacity Building: A Survey of Public Secondary Schools in Kenya. International Journal of Applied Research Studies, 2, 1-26.

[12] Fullan, M.G. (1991) The New Meaning of Educational Change. Cassell Educational Limited, London.

[13] Onguko, B., Abdalla, M. and Webber, C.F. (2008) Mapping Principal Preparation in Kenya and Tanzania. Education Management, Administration and Leadership, 46, 715-726. https://doi.org/10.1108/09578230810908307

[14] Komba, W.L. and Kumbi, E. (2008) Teacher Professional Development in Tanzania: Perceptions and Practices. Journal of International Cooperation in Education, 11, 67-83.

[15] UNESCO (2002) Education for All, Is a World on Track? EFA Global Monitoring Report.

[16] URT (2016) Waraka wa Elimu Namba 3 Wa Mwaka 2016 Kuhusu Utekelezaji wa Elimu Msingi bila Malipo. Wizara ya Elimu, Sayansi na Teknolojia, Dares salaam.

[17] HakiElimu (2017) The Impact of the Implementation of Fee-Free Education Policy on Basic Education in Tanzania: A Qualitative Study. HakiElimu, Dar es salaam.

[18] URT (1995) Education and Training Policy. Ministry of Education and Culture, Dar es salaam.

[19] Kelemi, M. and Osita, O. (1999) Public Expenditure and Delivery of Education in Kenya: Lessons from Secondary School. In: Cost Sharing in Education and Health, Tema Publishers, Dar es Salaam, 13-15.

[20] Kandasamy, M. and Blaton, L. (2004) School Principals: Core Actors in Educational Improvement: An Analysis of Seven Asian Countries. UNESCO, Paris.

[21] Liphan, J. (2016) The Principalship: Foundations and Functions. 3rd Edition, Harper and Row, New York.

[22] Ogba, F.N. and Igu, N.C. (2014) Realizing Quality Education in Nigeria: The Need to Revitalize Secondary Education. Journal of Education Research, 2, 57-64.

[23] Ndyali, H.S. (2013) The Role of School Head in Enhancing Students' Academic 
Performance in Community Secondary Schools in Mbeya Urban. APPS Thesis, Open University of Tanzania, Dar es Salaam.

[24] Alike, G.U. (2016) Constraints to Effective Management of Curriculum and Instruction in Anambra State Preparing Schools. UNIZIK Journal of Education Management and Policy, 1, 173-180.

[25] Musalia, F. (2005) Challenges Facing Head Teachers in the Implementation of Free Primary Education in Suba East Division, Migori District, Nyama Province. Unpublished M.ED. Thesis, University of Nairobi, Nairobi.

[26] Njideka, G. (2016) Management Competency Needs of Principals for Effective Administration of Secondary Schools in Nigeria. International Journal of Advanced Research in Education \& Technology, 3, 61-67.

[27] Alkarni, A. (2014) Problems Which May Challenge the Ability of Secondary School Head Teachers in the City of Tabuk to Lead Their Schools Professionally. ARECLS, 11, 55-74.

[28] Mtavangu, E.B. (2010) Challenges of Education Managers in Enhancing Equitable Access to Quality Secondary Education in Tanzania Mainland: A Case of Community Secondary Schools in Iringa. Unpublished M.ED. APPS Thesis, Open University of Tanzania, Dar es Salaam.

[29] Massawe, D. (2014) Assessment of Leadership Practices at School Level in Community Secondary Schools: A Case of Selected Schools in Kinondoni Municipality, Tanzania. Unpublished M.ED. APPS Thesis, Open University of Tanzania, Dar es Salaam.

[30] Ignace, A. (2014) Assessment of Heads of School's Strategies in Managing Conflicts in Secondary Schools: A Case of Kinondoni Municipality. Unpublished M.ED. APPS Thesis, Open University of Tanzania, Dar es Salaam.

[31] Mkanga, A.M. (2016) Instructional Leadership: The Role of Heads of Schools in Managing the Instructional Programme. International Journal of Educational Leadership and Management, 4, 30-47.

[32] TAHOSSA (2015) 2015 Singida Annual Performance Report.

[33] Cohen, L. (2000) Research Methods in Education. Routledge, London.

[34] Dunning, D. (2004) Flawed Self-Assessment: Implications for Health, Education and the Workplace. Psychological Science in the Public Interests, 5, 69-106.

[35] King, D. (2002) The Changing Face of Leadership. Educational Leadership, 59, 61-63.

[36] Kamete, J. (2014) The Influence of Headmaster's Managerial Skills on Effective School Management: A Case of Public Secondary Schools in Mbeya Tanzania. Unpublished M.ED. Thesis. Open University of Tanzania, Dar es Salaam.

[37] Esudu, S. (2010) Influence of Head Teachers' General and Instructional Leadership. Journal of Universal Primary Education, 21, 21-24.

[38] Gerumi, S. (2003) Instructional Supervision: Its Impact on Teachers' and Students' Performance. Unpublished M.A. Thesis, University of Nueva Caceres, Naga.

[39] Zepeda, S.J. (2003) Instructional Supervision: Applying Tools and Concepts. Eye on Education, New York.

[40] Heaton, R.M., Lewis, W.J., Spillane, J.P. and Pustejovsky, J. (2009) Understanding Teacher Leadership in Middle School. Mathematics: A Collaborative Research Effort. Journal of Mathematics and Science: Collaborative Exploration, 11, 19-40.

[41] Monyxpenny, H.H. and Pridaux, K. (2013) Principalship in an Indonesian School Context: Can Principal Decision Making Styles Significantly Predict Teacher Job 
Satisfaction? School Leadership and Management, 32, 453-471.

[42] Hallinger, P. and Walker, A. (2014) Exploring Whole School vs. Subject Department Improvement in Hong Kong Secondary Schools: School Improvement and School Effectiveness. http://www.researchgate.net

[43] World Bank (2010) Recruiting, Retaining, and Retraining Secondary School Teachers and Principals in Sub-Saharan African. The World Bank, Washington DC.

[44] Lwaitama, A.L. and Galabawa, J.C.J. (2008) Community Secondary Schools: How Long Is Their Journey to Quality Education. Tanzania Education Network, Dar es salaam.

[45] Fullan, M. (1992) The New Meaning of Educational Change. Teachers College Press, Ontario.

[46] Mobegi, O., Ondigi, B. and Oburu, O. (2010) Secondary School Headteachers' Quality Assurance Strategies and Challenges in Gucha District, Kenya. Education Research and Reviews, 5, 408-414.

[47] Femi, D. and Segun, O. (n.d.) The Craft of Educational Management. http://www.afusatalabi.com.ng/school_personnel_management.pdf

[48] Mfaume, H. and Bilinga, M. (2017) Prevalence of Teachers' Professional Malpractices in Tanzania Public Schools. What Ought to Be Done? Journal of Educational Training Studies, 5, 43-52. https://doi.org/10.11114/jets.v5i2.2106

[49] Mbiti, D. (2007) Foundations of School Administration. Oxford University Press, Nairobi.

[50] Ikediugwu, N.P. (2016) Administrative and Management for Effective Secondary School Management. Journal of Educational Management and Policy, 1, 1-7.

[51] Adaegbe, S.U. (2016) Curriculum Innovation and the Secondary School Principals. Institute of Education University Press, Ife.

[52] Njeru, J.W. (2004) Financial Management Practices of the Head Teachers in Public Secondary Schools in Central Division, Embu District, Kenya. Unpublished MA Thesis in Educational Administration and Planning, University of Nairobi, Nairobi.

[53] Orlosky, T. (2004) Managing the Primary Schools. Dvid Fulton, London.

[54] Mgeni, V.A. (2015) The Effectiveness of Secondary School Budgets in the Implementation of School Projects in Sengerema District Mwanza. Unpublished M.ED. APPS Thesis, Open University of Tanzania, Dar es Salaam.

[55] Summers, T.J. (2005) Leadership for the Schoolhouse. How Is It Different? Why Is Important? A Wiley Company, San Francisco.

[56] Makongo, M. and Mbilinyi, M. (2003) The Problem of Democratizing Education at the Local Level. HakiElimu Working Papers Series, HakiElimu, Dar es salaam.

[57] Coleman, S. (2003) Managing Schools in South Africa: Leadership and Strategic Management in South Africa. The Commonwealth Secretariat, London.

[58] URT (2015) Waraka wa Elimu Namba 6 Wa Mwaka 2016 Kuhusu Utekelezaji wa Elimu Msingi bila Malipo. Wizara ya Elimu, Sayansi na Teknolojia, Dar es salaam.

[59] Mutisya, M.M. (2011) Impact of Free Secondary Education on Quality of Secondary Education in Katangi, Yatta District-Machakos County, Kenya. Unpublished M.ED. Thesis, Kenyatta University, Nairobi.

[60] Kattan, R.B. (2006) Implementation of Free Basic Education Policy. The World Bank Education Working Papers Series, No. 7.

[61] Twaweza (2016) A New Dawn? Citizens' Views on New Developments in Education. Sauti za wananchi, Brief No. 30 . 
[62] Ngowi, F.L. (2015) Examining Impact of Unreliable Government Disbursement of Capitation Grants on Academic Performance in Public Secondary Schools: The Case of Kinondoni District. Unpublished M.ED. Thesis, Open University of Tanzania, Dar es Salaam.

[63] Njunwa, K.M. (2010) Community Participation as a Tool for Development: Local Community's Participation in Primary Education Development in Morogoro, Tanzania: A Case of Kilakala and Mindu Primary Schools. Unpublished MA Thesis in Development Management, University of Agder, Kristiansand.

[64] Akobour, I.R., et al. (2015) Community Participation in Educational Infrastructure Development and Management in Ghana. Education, 5, 129-141.

[65] Epri, M.L. (2016) A Case Study on the Impact of Large Classes on Student Learning. Contemporary PNG Studies. DWU Research Journal, 24, 95-109.

[66] Blachford, P., Basset, P., Goldstein, H. and Martin, C. (2003) Are Class Size Differences Related to Pupils' Educational Progress and Classroom Processes? Finding from the Institute of Education Class Size Study of Children Aged (5-7) Years. Institute of Education, University of London, London.

[67] Yaman, H. and Uygulamada, K. (2009) Teachers' Views and the Applicability of the Turkish Course Curriculum in Crowded Primary Classrooms. Egitim.

[68] Kuluchumila, R.C. (2014) Preparation and Development of Secondary School Heads.

[69] Lindon, J. (2011) Creating a Culture of Coaching: Up-Skilling the School Workforce in Times of Change. National College for Leadership of Schools and Children's Services, Nottingham.

[70] Archer, D., et al. (2010) Politics of Participation: Parental Support for Children's Learning and School Governance in Burundi, Malawi, Senegal, and Uganda. University of London, London. 


\section{Appendix I: Questionnaire for Teachers and Municipal Secondary Education Officers}

Dear respondent,

I am Tanzania Public Service College (TPSC) Singida Campus staff. As part of my responsibilities and core business of our college, I am undertaking a study entitled "FREE SECONDARY EDUCATION AND THE CHANGING ROLES OF THE HEADS OF PUBLIC SCHOOLS IN TANZANIA: ARE THEY READY FOR THE NEW RESPONSIBILITIES?"

Kindly fill out the questionnaire as honestly as possible. If the space provided is not sufficient please feel free to use additional sheets of paper. All responses supplied will be used only for academic study purposes.

Thank you.

1) Name of school/Local Government Authority

2) Below you can find statements about work performance of Heads of school. Please rate their performance. Tick $(\sqrt{ })$ one choice in each row: $D=$ Done; WD $=$ Well done; $\mathrm{PD}=$ partially done; $\mathrm{ND}=$ not done; Not sure (NS)

\begin{tabular}{|c|c|c|c|c|c|c|}
\hline \multicolumn{7}{|c|}{ Instructional Leadership Capacity } \\
\hline S/N & Items & $\mathrm{D}$ & WD & PD & ND & NS \\
\hline i. & $\begin{array}{l}\text { Heads of school observe teaching and learning activities } \\
\text { in classrooms }\end{array}$ & & & & & \\
\hline ii. & $\begin{array}{l}\text { Heads of school supervise teachers' lesson plans and } \\
\text { schemes of work }\end{array}$ & & & & & \\
\hline iii. & $\begin{array}{l}\text { Heads of school make available facilities accessible to all } \\
\text { teachers and students }\end{array}$ & & & & & \\
\hline iv. & $\begin{array}{l}\text { Heads of school evaluate the planning and } \\
\text { implementation of curriculum programmes }\end{array}$ & & & & & \\
\hline v. & $\begin{array}{l}\text { Heads of school give teachers suggestions as to how they } \\
\text { can improve their teaching }\end{array}$ & & & & & \\
\hline vi. & $\begin{array}{l}\text { Heads of school jointly solve classroom problems with } \\
\text { teachers }\end{array}$ & & & & & \\
\hline vii. & Heads of school monitor students' works & & & & & \\
\hline viii. & $\begin{array}{l}\text { Heads of school ensure proper records school like } \\
\text { attendance registers and student enrolment }\end{array}$ & & & & & \\
\hline ix. & $\begin{array}{l}\text { Heads of school ensure that staff in different } \\
\text { departments and work positions work cooperatively and } \\
\text { not antagonistically for the common goals of schools }\end{array}$ & & & & & \\
\hline $\mathrm{x}$. & $\begin{array}{l}\text { Heads of school make sure that subjects and classes are } \\
\text { assigned to teachers according to their qualifications } \\
\text { and competences }\end{array}$ & & & & & \\
\hline
\end{tabular}


Personnel Management Capacity

\begin{tabular}{llllll}
\hline S/N & Items & D & WD & PD & ND
\end{tabular}

Heads of school keep records of staff properly and accurately

ii. Heads of school model the behaviors they expect from staff

iii. Heads of school communicate effectively and timely with staff

iv. Heads of school motivate, encourage and persuade their staff

v. Heads of school praise in public and criticize in private

vi Heads of school involve staff in decision-making and matters concerning staff

vii Heads of school delegate duties and authorities to capable staff

viii. Heads of school do not take sides in conflict resolutions

ix Heads of school defuse tense situations and negotiate solutions

Heads of school encourage and enable appropriate $\mathrm{x}$ professional development of staff

\begin{tabular}{llllllllll}
\hline \multicolumn{1}{c}{} & \multicolumn{1}{c}{ Financial Management Capacity } & & & & & \\
\hline S/N & Items & D & WD & PD & ND & NS
\end{tabular}

Heads of school supervise and monitor expenditure of

i. school funds per government directives and financial regulations

ii. Heads of school jointly prepare school budget with the management staff and heads of department

Heads of school prioritize financial allocation according to needs

iv. Heads of school ensure that school budgets reflect agreed goals and objectives

Heads of school delegate the mechanism of financial matters to capable staff

vi Heads of school work within the constraints of school budgets

vii

Heads of school keep financial information of their schools accurately

viii. Heads of school give true information about financial positions of their schools

ix Heads of school use school budget for decision making Heads of schools keep inventories of school assets properly 
3) Are there challenges faced by Heads of public secondary schools in the implementation of free education policy? Please mention them below:

a)

b)

c)

d)

e)

4) What strategies do heads of schools use to cope with the challenges of free education policy? Please mention them below:

a)

b)

c)

d)

e)

Thank you for your responses 


\section{Appendix II: Questionnaire for Heads of Schools}

Dear respondent,

I am Tanzania Public Service College (TPSC) Singida Campus staff. As part of my responsibilities and core business of our college, I am undertaking a study entitled "FREE SECONDARY EDUCATION AND THE CHANGING ROLES OF THE HEADS OF PUBLIC SCHOOLS IN TANZANIA: ARE THEY READY FOR THE NEW RESPONSIBILITIES?"

Kindly fill out the questionnaire as honestly as possible. If the space provided is not sufficient please feel free to use additional sheets of paper. All responses supplied will be used only for academic study purposes.

Thank you.

Name of school

1) As head of school, what challenges do you face in the implementation of free education policy? Please mention them below:

a)

b)

c)

d)

e)

2) What strategies do you employ to cope with the challenges of free education policy? Please mention them below:

a)

b)

c)

d)

e)

Thank you for your responses 